\title{
Kontoere in die ontwikkeling van 'n missionêre ekklesiologie in die Nederduitse Gereformeerde Kerk - 'n omvangryker vierde golf
}

\begin{abstract}
Contours in the development of a missional ecclesiology in the Dutch Reformed Church - a more comprehensive fourth wave.

This article is a response to the description of Dutch Reformed mission since 1990 as mission "to the ends of the earth" in Willem Saayman's book Being Missionary - Being Human. An overview of Dutch Reformed Mission. Saayman distinguish four eras or waves of extraordinary mission endeavour. It is argued that the 4th wave identified by Saayman as an unfolding wave with particular emphasis on mission work outside local communities and South African borders, must be understood in a more comprehensive way. There is clear indication of an emerging missional ecclesiology in the policy decisions of the Dutch Reformed Church. A study of these policy decisions leads to the conclusion that a renewed commitment to Africa and to the healing of South Africa as well as a new missional paradigm are paving the way for a focus on local communities. The mission spiral of mission "far away" has made a turn "at home".
\end{abstract}

\section{INLEIDING}

Willem Saayman het in sy belangrike sendinggeskiedenis van die Nederduitse Gereformeerde Kerk (NGK), Being Missionary - Being Human. An overview of Dutch Reformed Mission, die oorsig oor die NG Kerk ingedeel in vier golwe. Met verwysing na die sosiale analise van Max Weber het hy vier bewegings in die geskiedenis van die NG Kerk aangedui wat elk gekenmerk is deur ' $n$ opwelling en ' $n$ tydperk van buitengewone sendingbedrywighede. ' $n$ Golf is ' $n$ omvangryke beweging wat nou verwant is aan belangrike en bepalende gebeure in die SuidAfrikaanse en wêreldgeskiedenis. So ' $n$ golf dui op ' $n$ verandering in rigting wat die lewens van die meerderheid kerklidmate en predikante aanraak. Dit het ook te doen met die identifisering van nuwe sendinggeleenthede (Saayman 2007:9-13). Hierdie studie sluit aan by Saayman se vierde golf en beskryf die kontoere in die ontwikkeling van 'n missionêre ekklesiologie in die tydvak wat volgens hom in 1990 'n aanvang geneem het. Die sosiale konteks van die vierde golf is die demokratiese Suid-Afrika wat 'n aanvang geneem het met mnr. FW de Klerk se dramatiese toespraak op 2 Februarie 1990. Hofmeyr en Kruger (2009:387) het aangedui dat sulke sosio-kulturele veranderings belangrike implikasies vir die identiteit van die NG Kerk het. Die demokratiseringsproses in Suid-Afrika en globalisering dien juis as sosio-kulturele agtergrond vir die nuwe rigting wat sending in die NG Kerk sedertdien ingeslaan het.

Die gesprek word opgeneem waar Saayman dit afsluit met sy opmerking dat die vierde golf fokus op die "eindes van die aarde". Daar word aangevoer dat hy dit voortydig beskryf het as sending na "die eindes van die aarde." Dit is duidelik dat daar wel van 'n vierde golf gepraat kan word, maar dit moet eerder tipeer word as die herontdekking van die missionêre aard van 
die plaaslike gemeente. Die beskrywing van die golf moet omvattender moet wees as bloot "na die eindes van die aarde". Dit is eerder ingebed in 'n missionale renaissance wat gesteun word deur 'n nuwe verstaan van die aard en wese van die kerk en uitloop op 'n globale en lokale fokus. Hierdie globale en lokale fokus word soms in Engels as "glocal" beskryf en dui aan dat dit 'n globale dimensie na die "eindes van die aarde" het, maar dat die vierde golf lokaal ruimer verstaan moet word sodat dit ook die NG Kerk se gerigtheid op Suid-Afrika en plaaslike gemeenskappe insluit.

\section{'N OMVANGRYKER VIERDE GOLF}

Hoewel Saayman (2007:106,117) verwys na twee betekenisvolle besluite van die Algemene Sinode, naamlik die definisie van sending in die Sendingreglement van 1998 en die Roepingsverklaring van 2002, laat sy beskrywing nie reg geskied aan die ontwikkelings wat sedertdien op hierdie besluite gevolg het nie. Daarom word die kontoere van die NG Kerk se ontluikende missionêre ekklesiologie verder gevolg en geïnterpreteer in die lig van resente ontwikkeling in die NG Kerk rondom missionêre ekklesiologie. Die verdere ontwikkelings was so duidelik dat daar selfs stemme was wat in die wandelgange tydens die vergadering van SAWS (Suid-Afrikaanse Werkgemeenskap vir Sendingwetenskap) in 2010 gepraat het van 'n nuwe golf van sending in Suid-Afrika. Dit is nie 'n nuwe vyfde golf nie, maar eerder 'n geval dat die aard, rigting en omvang van die vierde golf nou eers duidelik word. Daarom word sinodebesluite en beleidstandpunte van die Algemene Sinode en enkele streeksinodes van die NG Kerk ondersoek en die kontoere van 'n ontluikende missionêre ekklesiologie aangebied as 'n korrektief op, maar ook uitbreiding van die vierde golf.

Dié verruiming van die vierde golf is duideliker sigbaar in die verskuiwing in die manier waarop daar oor die kerk en gemeentes gedink word. Dit raak veral die verstaan van die kerk se deelname aan God se werk in die wêreld. Begrippe soos "gestuurde gemeentes" en "missionêre ekklesiologie" word oral gehoor. In die NG Kerk is daar gemeentes wat hulleself beskryf as missionêre gemeentes. Daar is werkswinkels en vennootskappe en seminare oor gemeentes en hoe hulle betrokke kan raak by hulle gemeenskappe. Meer as 170 gemeentes was teen 2010 lid van die Suid-Afrikaanse Vennootskap van Gestuurde Gemeentes (SAVGG) (Niemandt 2010) Party gemeentes het hulle name verander en staan bekend as "gemeenskapskerke". Die saak het ook ter sprake gekom by kerkvergaderings. 'n Enkele voorbeeld: Die NG Kerk Sinode Hoëveld verander sy visie in 2005 om te lui: "Die Sinode van Suid-Transvaal (a) begelei gemeentes om God te eer, mekaar en die wêreld met Christus se liefde te dien; en (b) begelei gemeentes sodat die NG Kerk in Suid-Transvaal groei na'n gestuurde kerk vir die samelewing". (Sinode van SuidTransvaal van die Nederduitse Gereformeerde Kerk 2005). Die Algemene Sinode het sedert die sinode in 2002 in sy "Roepingsverklaring" sterk gefokus op die NG Kerk se roeping in die wêreld - veral in Suid-Afrika én in Afrika met hul geweldige uitdagings:

"Tydens die vergadering van die Algemene Sinode 2002 het ons as afgevaardigdes al hoe meer oortuig geraak van die liefde van Christus en daarom ook van die NG Kerk se roeping en plek in Suider-Afrika. Daarom:

(a) verbind ons ons opnuut aan die Here wat ons Kerk 350 jaar gelede hier geplaas het. Ons dank Hom vir die voorreg om ook nou nog deel van sy kerk te kan wees. Ons is daarvan oortuig dat net die evangelie van Christus ons op 'n pad van heil kan plaas. Daarom wil ons as kerk die Woord van die Here tydig en ontydig verkondig en orals getuienis aflê van die hoop wat in ons leef.

(b) verbind ons ons opnuut tot ons kontinent, in die besonder Suider-Afrika. Die tragiese verhale van die allerverskriklike vorme van geweld, die geweldige omvang van armoede en 
gevolglike hongersnood, die konsekwensies van die vigspandemie, die gebrek aan respek vir mense, diere en die omgewing en ook ons aandeel daaraan, het ons ontstel. Die Sinode betuig sy meegevoel aan die talle slagoffers. Ons wil ook ' $n$ verskil maak. Daarom verbind ons ons om mee te werk aan oplossings vir ons samelewing. Ons stel ons as kerk beskikbaar om op elke vlak waar ons kan help, betrokke te raak. Ons verseker die owerheid van ons voorbidding en ons verbintenis tot diens aan die gemeenskap.

(c) verbind ons ons tot groter eenheid met ander kerke. Ons wil graag herenig met ons Kerk-familie, soos ons glo God dit wil hê. Ons wil ook graag ons ekumeniese bande bevestig en uitbrei en met alle ander Christene hande vat om ons lande op te bou en pynlike omstandighede te verlig.

(d) roep ons ons gemeentes op om by die genesing van ons lande betrokke te raak. Ons dank die Here vir die toegewydheid van lidmate en die talle positiewe aksies waarvan ons orals hoor. Kom ons wys die wêreld opnuut dat ons as sout van die aarde en lig vir die wêreld God se koninkryk wil laat kom.

Ons het 'n Here. Ons is hier. Ons is Sy kerk.

Aan God al die eer." ～(Nederduitse Gereformeerde Kerk 2002 = NGK 2002:604)

Die gerigtheid op Suid-Afrikaanse gemeenskappe is deur die Algemene Sinode van 2007 herbevestig en lidmate en gemeentes is aangespoor om met nuwe moed en oortuiging aan te meld en om in die lig van God se werk in die wêreld (missio Dei) en die kerk se missionêre taak hul verantwoordelikheid raak te sien en na te kom. Die Roepingsverklaring van 2007 spits die verklaring van 2002 verder toe en lui onder meer:

"Christus, die Hoof van die kerk, stuur ons om ons roeping te gehoorsaam en ons daaraan toe te wy... om met openheid onvoorwaardelik diensbaar te wees in die wêreld. Ons wil graag met alle ander Christene hande vat om ons samelewings op te bou en pynlike omstandighede te verlig. Ons wil mekaar as gemeentes en leiers met liefde aanspoor, begelei en toerus om by die genesing van ons lande betrokke te raak. Ons is beskikbaar en is verbind tot diens aan gemeenskappe. Ons dank die Here vir die toewyding van lidmate en die talle positiewe aksies waarvan ons oral hoor. As gestuurde gelowiges is ons sout van die aarde en lig vir die wêreld. Ons staan in diens van die koms van God se koninkryk" (NGK Die Kerkorde 2007).

\section{EKUMENIESE KONTEKS EN INTERNASIONALE DISKOERS}

Saayman gee in sy beskrywing van elkeen van die vier golwe aandag aan die sosiale en politieke konteks en skets telkens ook die globale perspektief wat die omstandighede in Suid-Afrika en die NG Kerk beïnvloed. Die impak van die demokratiseringsproses en globalisering het sendingwerk na die eindes van die aarde moontlik gemaak (Saayman 2007:111-112), maar hy verreken die impak van globalisering op die NG Kerk en ander kerke in Suid-Afrika nie ten volle nie.

Die konteks waarteen die vierde golf afspeel behoort verruim te word deur kennis te neem van die feit dat die ontwikkelings in Suid-Afrika ingebed is in ' $n$ globale missionale renaissance (McNeal 2009:1). Die verstaan van sending as die kerk se deelname aan God se werk in die wêreld, en die implikasies hiervan vir plaaslike gemeentes, was onder meer een van die belangrike temas van die sendingkonferensie in Edinburgh in 2010. By Edinburg 2010 staan die saak tewens in die kern van die gesprek: God is die sturende God en die kerk word uitgenooi om deel te neem aan hierdie sending van God (Balia \& Kim 2010:23-26). Die nuwe Wêreldgemeenskap van Gereformeerde Kerke het sy visie ook in missionêre taal uitgespel en sê onder meer dat die lidkerke geroep is om deel te neem aan God se transformasie van die wêreld 
(World Communion of Reformed Churches 2010=WCRC 2010). Kim (2009:23-27) gee 'n oorsig van die byeenkomste van die International Missionary Council en die Wêreldraad van Kerke. Sy dui aan dat die ekumeniese verstaan van sending gegroei het tot konsensus oor die feit dat dit ' $n$ sendinggesentreerde kerk is. Die missio Dei het die oorkoepelende paradigma van haas alle Christelike kerke geword en die kerk word verstaan as diensbaar aan God se sending in die wêreld (Kim 2009:30). Die diskoers in twee denominasies dien as verdere aanduiding hiervan. In die Anglikaanse kerk is dit vervat in die boek Mission Shaped Church (The Archbishops' Council 2004) en Nederland het die Protestantse Kerk in Nederland (PKN) 'n program Kerk naar buiten (PKN 2010). Dit verbaas dus nie dat McNeal (2009:xv) hierdie missionêre gerigtheid as 'n bepalende kenmerk van hoofstroomdenke oor kerkwees sien nie.

Daar moet melding gemaak word van die invloed van die Gospel and Our Culture Network (GOCN), waarbinne teoloë soos Keifert, Guder, Van Gelder en Hunsberger die werk van Bosch en Newbigin verder ontwikkel en belangrike leiding verskaf oor die missionêre aard van die kerk (Guder 2000:xi-xiv, Keifert 2007:12). Hierdie nadenke het 'n belangrike rol in die NG Kerk gespeel. So word dit by name gemeld in die verslag van Algemene Kommissie vir Diensgetuienis aan die Algemene Sinode van 2004 en word erkenning gegee aan die feit dat Suid-Afrika deel van die netwerk is en dat daar besinning gedoen word oor "... die missionêre roeping van die kerk en veral oor plaaslike gemeentes in eie konteks." (NGK Agenda 2004:35)

Dit is duidelik dat daar ' $n$ groeiende konsensus oor die missionêre aard van die kerk is - ' $n$ verskuiwing van 'n kerkgesentreerde sending na 'n sendinggefokusde kerk. Dit het so belangrik geword dat Christelike kerke wat so sendinggefokus is, amper onherkenbaar anders lyk as kerke wat nie daardie fokus het nie.

\section{'N NUWE MISSIONÊRE IDENTITEIT VIR DIE NGK}

Die teologiese ontwikkelings wat uitgedruk is in besluite van die ekumeniese byeenkomste, teologiese insigte in die wyse waarop die missio Dei ekklesiologie bepaal en die groeiende belangstelling in missionêre identiteit, het ' $n$ belangrike rol gespeel in die denke oor die identiteit van die NGK. Die kontoere van 'n ontluikende missionêre ekklesiologie kan juis gevolg word deur die NG Kerk se verstaan van sy identiteit aan die orde te stel.

Die NG Kerk se identiteit word deur sy Gereformeerde aard bepaal. Tydens die Sinode van 2007 het die kerk hierdie aard en karakter as volg uitgedruk:

"In die Gereformeerde teologie is daar oor die jare telkens teruggegryp na die boustene van die Reformasie en is die kernsake telkens nuut interpreteer. Een van die bondigste maniere om Gereformeerdheid uit te druk, is via die vier 'solas'."

Die bekende vier "solas" word dan genoem, naamlik die fokus op die Skrif alleen, die sentrale rol van Christus in die bemiddelingsproses, die fokus op genade alleen en geloof alleen.

“Oor elkeen van hierdie 'solas' is daar met reg boeke vol geskryf. Hierdie solas kom uiteindelik vir gereformeerdes tuis onder die dak van soli deo gloria (aan God alleen die eer).... Dit gee uitdrukking aan die leuse van die Reformasie dat ons altyd weer volgens die Skrifte moet reformeer (semper reformanda)" (NGK Agenda 2007:13).

Dit is opvallend dat die NG Kerk moeite doen om die oproep van die Reformasie tot voortdurende reformasie met nadruk te stel. Dit verduidelik ook hoekom die kerk soveel waarde heg aan die verstaan van sy konteks en gedurigdeur besig is om sy bedieninge nuut te oorweeg. Die kerk word voortdurend uitgedaag - hoe kom die Evangelie tuis in nuwe omstandighede? Hoe lyk die kerk se sending in die hedendaagse wêreld? 
Wanneer daar oor die wese van die kerk en die kerk se sending gepraat word, begin die gesprek altyd by God self. Sedert die byeenkoms van die International Missionary Council in Willingen in Duitsland in 1952 is die denke oor sending, onder die invloed van Hartenstein en Barth, bepaal deur die kerk se lewe in die Triniteit (Kim 2009:27-28). Newbigin (1995:29) het sending in sy bekende The Open Secret - An introduction to the theology of Mission, beskryf as die verkondiging van die koninkryk van die Vader, om lewe in die liefde van die Seun met almal te deel en om getuies van die Gees te wees. Dit moet ook verstaan word teen die agtergrond van die herontdekking van die Triniteitsteologie (Venter 2009:544).

Die kontoere van die NG Kerk se ontluikende missionêre ekklesiologie word ook deur die kerk se lewe in die Triniteit bepaal. Die NG Kerk sien die kern van Gereformeerde identiteit as 'n gerigtheid op God. Die Latynse frase coram Deo beskryf in 'n neutedop waaroor dit vir gereformeerdes gaan. Die lewe van 'n Christen is 'n lewe voor God. 'n Lewe gerig op God (NGK Agenda 2007:13). Die Algemene Sinode het hierdie sterk verbintenis van die kerk aan die drieenige God reeds in 2002 verwoord:

"Deur Christus is die kerk verbind aan die drie-enige God van die Bybel - Vader, Seun en

Gees. Ons glo dat die kerk aan die drie-enige God alleen behoort en in verbondenheid met Hom bestaan. Die kerk is die volk van God, die liggaam van Christus en die tempel van die Gees. Alles wat ons is en doen - ons identiteit, ons missie en ons bediening - word deur hierdie verhouding bepaal. Dat alles wat die kerk is en doen gedefinieer (behoort te) word deur sy verhouding met die lewende God, is die eerste en mees basiese beginsel van kerkwees. En die God van wie ons hier praat is die drie-enige God wat ons in die Ou en Nuwe Testament leer ken as Vader, Seun en Gees" (NGK Agenda 2002).

Dit word verder gevoer in die Sinode van 2004 as daar in 'n verslag oor gestuurde gemeentes gepraat word van die "fundering" van die roeping van die gemeente in die Triniteit. Die onderlinge verhouding van die persone in die drie-eenheid en die eenheid in die Triniteit het "heerlike implikasies vir die verstaan van die kerk se roeping" (NGK Agenda 2004:35). Sending is geheel en al die werk van die drie-enige God, Skepper, Verlosser en Saligmaker, ter wille van die wêreld, waaraan die kerk bevoorreg is om deel te neem. Die Reglement vir die Sending/ Getuienis verduidelik dit as volg: "Sending is die heilshandeling van die drie-enige God, Vader, Seun en Heilige Gees met die wêreld, waardeur Hy deur uit die ganse menslike geslag vir Hom 'n gemeente deur sy Woord en Gees vergader" (NGK Die Kerkorde 2007:104).

\section{MISSIO DEI}

Die wese van die kerk en die sending van die kerk is ingebed in die verstaan van die kerk se lewe in die Triniteit. Die drie-enige God op wie die bestaan van die kerk gerig is, is ' $n$ sturende God. Dit het tot ' $n$ wydlopende konsensus oor en verstaan van die missio Dei gelei. Sending is God se sending en behoort tot die wese van Christenskap en kerkwees (Kim 2009:26). God is'n sturende (missionêre) God. Die kerk en die kerk se sending word vanuit die sturende aard van God self verstaan. Die lewe van God is 'n proses van gestuurdheid: die Vader stuur die Seun, die Seun stuur die Heilige Gees. God het die wêreld so lief dat Hy sy enigste Seun stuur om nuwe lewe te bring. Vader, Seun en Heilige Gees stuur die kerk in die wêreld in (Bosch 1991:390). Bosch stel dit duidelik: dit is nie net ' $n$ geval dat God sending doen nie, Hy is sending. Dit is God wat die eerste inisiatief geneem het: Die Vader het in liefde na die mensdom uitgereik en sy Seun gestuur. Die Seun het as eerste Gestuurde na die aarde gekom om God se heilsplan in werking te stel. Met die 
voltooiing van Jesus se werk, het die Vader en die Seun die Heilige Gees na die wêreld gestuur om God se heilswerk te bevestig. Die sturende God stuur sy kerk nou ook uit om deel te neem aan God se sending. Dit is deel van die kerk se wesensaard, die kerk se DNA, om as gestuurdes te leef (Hirsch 2006:18).

Die NG Kerk beskryf haar Gereformeerde identiteit in hierdie taal: “Die roeping van die kerk kan as Gestuurdes van God omskryf word. Die kerk behoort in wese altyd op die wêreld gerig te wees en op pad na die wêreld te wees" (NGK Agenda 2007:14).

Sending behoort dus nie aan die gemeente nie, dit is nie iets kosbaar wat gehoorsame mense doen nie, dit is ten diepste 'n eienskap van God self. God is 'n skeppende God wat alles gemaak het. God werk ook steeds in sy skepping deur die Heilige Gees. Die Gees herstel die stukkende verhoudings sodat God se nuwe bedeling, sy Ryk, kan kom. Hierdie nuwe bedeling is een waar die versoeningswerk van Jesus Christus dit moontlik maak dat die verhouding van elke stukkie van die lewe met God herstel kan word. Anders gestel - God se werk in sy skepping behels dat hy besig is om sy Ryk te laat aanbreek in elke enkele aspek van die skepping. Sending is dus God se beweging na die wêreld en die kerk is ' $n$ instrument in daardie sending. Die saak word as volg verduidelik in 'n verslag aan die Algemene Sinode van 2004: "Belangrik is die herontdekking van en herbesinning oor die begrip Missio Dei. Die kerk se roeping is nie in die eerste plek om te stuur nie, maar om opgeneem te word in en deelhebber te wees van God se sending na die wêreld. Dit is God wat stuur. Die kerk se wesenlike roeping is dus om self gestuurde te wees" (NGK Agenda 2004:35). Die begrip dat die kerk nie ' $n$ doel op sigself is nie, maar instrument in God se sending, is kenmerkend van die ontluikende missionêre ekklesiologie in die NGK.

\section{GOD SE SENDING EN DIE KERK SE SENDING}

Die sending van God mond uit in die sending van die kerk. Die missio Dei bepaal die missio ecclesiae. Die missio Dei is die diepste grond vir die missio ecclesia (Heyns 1978:374, Bosch 1991:370). Die kerk is sending en neem deel aan God se sending want dit kan eenvoudig nie anders nie. Dit is presies hoekom die kerk bestaan - die kerk is geskep en gebore vir dié doel (Van Gelder 2007:93). Die kerk is die vrug van God se sending en bestaan om deel te neem en diensbaar te wees aan die voortgang van daardie sending.

Die getuienistaak van die kerk is 'n omvattende taak wat op die nood van die wêreld in al sy dimensies gerig moet wees. Die liefde van die Here moet in woord en daad verkondig word, én in die lewe van die kerk gedemonstreer word. Die kerk word geroep, bymekaargemaak en gestuur om die boodskap van liefde verder te dra. Wanneer daar dan van 'n gestuurde kerk gepraat word, verduidelik dit iets van die wese van die kerk. Dit is om deel te neem aan God se sending. Keifert (2007:30) som dit op: Die kerk is 'n geloofsgemeenskap wat deur God geroep, versamel, gefokus en gestuur word na die wêreld.

Hierdie verstaan word ook raakgesien in die Roepingsverklaring van die NG Kerk (2007) wanneer die kerk sê: "Ons besef opnuut God roep die NG Kerk deur sy Woord en Gees om aan Hom te behoort. Christus, die Hoof van die kerk, stuur ons om ons roeping te gehoorsaam en ons daaraan toe te wy om met'n leerbare gees die wil van God deur sy Woord te leer ken en uit te leef in die uitdagende en komplekse wêreld waarin ons lewe." (NGK Die Kerkorde 2007)

Die ontluikende kontoere van die NG Kerk se missionêre ekklesiologie dui aan dat daar in die kerk instemming is dat die sending van God uitmond in die sending van die kerk (NGK Agenda 2007:84, 85). Die feit dat die kerk verstaan word as beskermer maar ook as draer van die apostoliese waarheid, is al reeds by die Sinode in 2004 beskryf as die herontdekking van die "apostoliese karakter" van die kerk. Dit is nou duidelik hoekom die kerk se sendingtaak omvattend omskryf word. Die NG Kerk se Reglement vir die Sending/Getuienis (NGK Die Kerkorde 2007:104) 
gee 'n goeie opsomming van hoe dit verstaan word:

"Deur die gemeente laat God sy Woord aan die gevalle wêreld verkondig; bring Hy die gemeenskap van die heiliges uit alle nasies tot stand; laat Hy diens aan die wêreld in nood lewer; laat Hy sy opdrag om die skepping te bewaar en te bewerk sigbaar tot uitdrukking kom en word sy geregtigheid aan die samelewing en die wêreld verkondig. So laat Hy sy koninkryk kom tot by die voleinding van die wêreld."

Dit kan ook beter verstaan word uit die gesamentlike verduideliking van die NGK, die Nederduitse Gereformeerde Kerk in Afrika, die Reformed Church in Africa en die Verenigende Gereformeerde Kerk in Suider-Afrika (Gesamentlike verklaring 2006):

"Dit is 'n wesenskenmerk van die kerk as die liggaam van Christus ons Here en Verlosser, om deel te wees van God se sending in die wêreld (missio ecclesiae). Die gemeente, as plaaslike gestalte van die kerk en primêre instrument van God se sending, maar ook die kerk as geheel en elke lidmaat daarvan, is deur God gestuur."

Daar word in die gesamentlike verduideliking daarop gewys op die belang van ' $n$ lewe in die teenwoordigheid van God asook die opdrag om die Evangelie te bedien deur woorde en dade in 'n verhouding van liefde en eenheid. Die kerk moet streef na geregtigheid, versoening en heling en getuig van die hoop waarin ons lewe.

\section{GESTUURDE GEMEENTES}

Sending is nie iets wat die kerk doen nie, maar wat die kerk is. Die kerk word deur God in die wêreld gestuur om deel te neem aan God se sending. Wanneer die kerk dit nie doen nie, hou die kerk eintlik op bestaan (Kirk 1999:30). Sending is vir ' $n$ Christelike geloofsgemeenskap juis om te doen wat hulle gestuur is om te doen - en dit begin reg daar waar die gemeente haarself bevind. Die kerk is ' $n$ lewende organisme wat deur sy gestuurdheid gevorm en bepaal word. In 'n verslag aan die Algemene Sinode van 2004 word gesê dat dit nie in die eerste plek gaan om dit wat die gemeente doen nie, maar eerder om dit wat die gemeente is, naamlik “...om opgeneem te word in en deelhebber te wees van God se sending na die wêreld." (NGK Agenda 2004, Agenda:35) Dieselfde oortuiging klink op in die kerk se nadenke oor Gereformeerde Identiteit. Die kerk word beskryf as God se geskenk aan die wêreld. Die kerk is God se gestuurdes wat in wese op die wêreld gerig is en op pad na die wêreld moet wees (NGK Agenda 2007:14). Die Sinode van Suid-Transvaal besluit in 2005 op die volgende strategiese fokus: "Om gemeentes te begelei om 'n gestuurde kerk vir die samelewing te word deur (a) uit te reik na die gemeenskappe en deur (b) te groei na 'n bediening wat vir diversiteit voorsiening maak." (Hofmeyr en Kruger 2009:390391)

Die Apostolaatsteologie het die sending van die kerk sterk gefokus op die feit dat die kerk na die wêreld gestuur is. Net so min as wat daar aan die kerk gedink kan word sonder om van sending te praat, net so min kan aan die kerk gedink word sonder om van die kerk se verhouding met die wêreld te praat. Die kerk se bestaan, organisasie en ampte behoort hierdie gerigtheid op diens aan die gemeenskap te weerspieël (Kim 2009:31).

\section{SENDING EN KONINKRYK}

Nadenke oor die kerk se gestuurdheid is ten nouste verweef met nadenke oor God se Ryk. Kirk (1999:35) beskryf die verhouding tussen koninkryk, kerk en die wêreld in die deelname aan God se sending as 'n komplekse saak. Die kerk getuig oor en is 'n voorsmaak van God se koninkryk, maar is nie identies met die koninkryk nie. Die kerk kan eerder beskryf word as 'n lewende 
interpretasie van die koninkryk. Uiteindelik gaan dit om die koninkryk of die heerskappy van God in die wêreld - dit is die einddoel van die kerk se roeping tot getuienis. Die kerk is God se mense wat ' $n$ voorsmaak bied van God se genesende heerskappy. Die nuwe bedeling wat Jesus Christus bring, die versoenende heerskappy van God in Christus, gee deur die werk van die Gees geboorte aan die missionêre kerk. Die aard, bedieninge en organisasie word dus beslissend bepaal deur die werklikheid, krag en bedoeling van God se Ryk, wat beteken dat die wese van die kerk missionêr van aard is.

Die inweef van die koninkryk van God in die verstaan van die kerk se missionêre identiteit het die afgelope tien jaar al hoe duideliker in die NG Kerk geword. Hoewel die saak van die koninkryk so lank terug as in 1974 aan die orde gekom het (NGK 1974:39-53), is die koninkryk en die gestuurde aard van die kerk sedert 1990 baie nouer verbind. Die verslag oor gestuurde gemeentes stel dat die nadenke oor missionêre identiteit ook die saak van die verhouding tussen kerk en koninkryk onder die soeklig bring. In die verslag word gestel dat daar gewaak moet word teen 'n verkerkliking van die wêreld, of 'n kultuuroptimistiese ideaal dat die kerk die roeping het om self die koninkryk te bou of die wêreld te transformeer. Dit is en bly God wat self sy koninkryk bou, daarin gebruik Hy die kerk, maar ook ander instansies en individue as diensknegte en instrumente (NGK Agenda 2004:36).

Die saak van die koninkryk word ook opgeneem in die verklaring oor Gereformeerde Identiteit:

"Gereformeerdes het altyd 'n oog gehad daarvoor dat die koninkryk groter is as die kerk. God is nie "n afdelingshoof nie. Hy regeer oor die kosmos. Selfs al is die realiteit van die gebroke wêreld deurgaans teenwoordig, is daar ook orals tekens van die voorsienigheid en sorg van God sigbaar. Gelowiges het die roeping om orals tekens van die koninkryk op te rig en vanuit die heerskappy van God te leef" (NGK Agenda 2007:16).

Die koppeling van die missionêre verstaan van die kerk en diensbaarheid in God se ryk is veral sigbaar in die NG Kerk se Roepingsverklaring van 2007: "As gestuurde gelowiges is ons sout van die aarde en lig vir die wêreld. Ons staan in diens van die koms van God se koninkryk." (NGK 2007)

God se sending word in die wêreld en in die kerk uitgevoer. Die kerk kan nie anders om doelbewus te getuig oor die betekenis en impak van God se koninkryk nie, al is die kerk en die koninkryk nie presies dieselfde nie. Die ondersoek na ontluikende missionêre ekklesiologie van die NG Kerk dui aan dat dié saak die afgelope twintig jaar die aandag van verskeie sittings van die Algemene Sinode van die kerk geniet het.

\section{KONTEKS}

Die feit dat die kerk in wese altyd op die wêreld gerig is en op pad na die wêreld is, onderstreep hoe belangrik dit is om die konteks te verstaan. Keifert (2007:53) beskryf gestuurde gemeentes as gemeentes op 'n reis midde-in die werklikheid van die drie-enige God. Op hierdie reis is dit belangrik om ook in die "wêreld te wandel" - om vas te stel wat in die konteks aan die gebeur is. Dit herinner sterk aan Brouwer (2009:407) se beskrywing van 'n gemeente se ekologie waar hy verduidelik hoe belangrik dit is om sensitief te wees vir die feit dat gemeentes ingebed is en leef in interaksie met die gemeenskap.

Die herkenning van 'n gemeente se ekologie verg onderskeidingsvermoë - 'n liefde wat lei tot begrip en fyn aanvoeling om te onderskei waarop dit werklik aankom. Dit is dus beter om die klem eerder op luister en onderskeiding te laat val as op voorskriftelike bedieningsmodelle. Wanneer die kerk sy aard as gestuurde gemeenskap, sy geskiedenis en sy konteks verstaan, groei die kerk 
se verstaan van sy roeping. Dit verg begrip vir die prosesse van verandering in die transformering na gestuurde gemeente-wees (NGK Agenda 2004:36). Hierdie onderskeidingsvermoë het met luister te doen - om te luister na die Woord en om te luister na die wêreld (konteks).

Die Seisoen van Luister, wat in Mei 2005 geloods is, moedig gemeentes en sinodes in die NG Kerk aan “...om met nuwe toewyding na God, medegelowiges en die kontekste waarin ons ons bevind, te luister." (NGK Agenda 2007:3) Dit het baie belangrike implikasies vir die verstaan van die ontluikende missionêre ekklesiologie in die NGK. Die duidelike fokus om ruimtes te skep waar lidmate na die Woord van God, mekaar en die wêreld luister sodat daar doelgerig diensbaar geleef kan word in ' $n$ veranderende wêreld, het die vierde golf waarna Saayman verwys, beslis in ' $n$ ander rigting laat ontplooi as "na die eindes van die aarde". In 'n sekere sin het die Seisoen van Luister die diskoers oor sending na Jerusalem, Judea, Samaria en die eindes van die aarde presies geplaas binne die dinamika van die nimmereindigende spiraal waarna Saayman (2007:123) verwys. Die kerk van Christus is gestuur om die Evangelie te bring en uit te leef in Jerusalem en die eindes van die aarde. Saayman het die hoop uitgespreek dat die NG Kerk se Roepinsgverklaring van 2002 sal lei tot ' $n$ dringende hersiening van prioriteite en die gerigtheid in die NGK. Die Seisoen van Luister is die duidelikste aanduiding van ' $n$ omvangryker vierde golf. 'n Enkele geval verduidelik genoegsaam: In 2009 is ' $n$ proses binne die Seisoen van Luister geloods wat bekendstaan as "Groei oor Grense". Die doel is om gemeentes te begelei om in hulle plaaslike konteks oor grense te groei. Die proses poog om lidmate te help om sonder vooroordele en onbevange na mense te luister. Dit wil hulle help om deur grense te breek en na vreemde stemme te luister en veral vas te stel wat die Bybel sê oor bewegings oor grense (NGK 2010). Teen April 2010 het die proses baie aandag in die NG Kerk gekry. Die jaarlikse Pinksterreeks is gewy aan die tema "Groei oor grense". 23067 hulpmiddels oor die proses is in April van die webruimte afgelaai, 'n groei van 539\% teenoor Feb. 2010. 18053 elektroniese hulpmiddels oor Pinkster is afgelaai. Daar is ' $n$ boek oor die proses gepubliseer. Die skrywers (Van Wyk, Marais, Simpson, 2009) van Die vrou by die put gebruik die verhaal wat in Johannes 4 opgeteken is as vertrekpunt om te sê: God het ons gemaak met die behoefte om in gemeenskap met mekaar te wees. God het ons geroep om vir ander te leef, maar dit beteken om waarlik by hulle teenwoordig te wees. Die publikasie geniet rekordverkope. Van Wyk (2010:3) dui aan dat die Seisoen van Luister ' $n$ betekenisvolle beweging binne die NG Kerk van dominasie na diens is. Volgens Saayman (2007:124) kan die NG Kerk sy roeping in Afrika net ontdek deur gedeelde ervarings met ander Christelike geloofsgemeenskappe. Die Seisoen van Luister kan dalk daarin slaag om hierdie soort groei oor grense moontlik te maak.

\section{GEMEENTES}

Die nadenke oor God se sending, die koninkryk en die wêreld het die fokus veral op gemeentes laat val. In 'n verslag voor die Algemene Sinode van 2004 word gesê dat die klem verskuif het vanaf die institusionele kerk na die plaaslike vergestalting van die liggaam van Christus en van die sinode na die plaaslike gemeente (NGK Agenda 2004). Die kerk bestaan primêr op plaaslike vlak. Hoewel denominasionele en sinodale strukture belangrik is, is die plaaslike gemeente die eintlike gestalte van die kerk. Die plaaslike gemeente is die belangrikste rolspeler in die getuienistaak, wat deur God as sy agent in die gemeenskap aangestel is (NGK Agenda 2007:84-85).

'n Missionêre gemeente is 'n gemeente wat gevorm is deur die gemeente se deelname aan God se sending, naamlik om verhoudings in 'n gebroke wêreld te herstel na dit wat God se plan vir sy skepping is (Barrett et al 2004:x). Dit bepaal alles wat die gemeente doen - van eredienste tot opleiding, van uitreike tot gemeentelewe - want die kerk se roeping is om te onderskei wat God in die wêreld aan die doen is en daarby aan te sluit. 
Die NG Kerk is sedert die sinode van 2002 besig om sy verstaan van gemeentes, wat ook hul missionêre aard insluit, te verwoord (NGK Agenda 2007: $44-56$ ). In die omvattende verslag is die volgende van belang om die kontoere van ' $n$ ontluikende missionêre ekklesiologie in te vul:

- Die gemeente word gesien as 'n gemeenskap van gelowiges wat koinonia met mekaar beleef. Dit gaan om nuwe verhoudings wat gekenmerk word deur liefde en onvoorwaardelike lojaliteit aan mekaar as lede van een familie (NGK Agenda 2007:46).

- Gemeentes fokus op die koninkryk van God. Lidmate is Jesus se voltydse dissipels wat gekenmerk word deur "...hul lojaliteit aan Christus en sy plan om die koninkryk van God wêreldwyd te laat seëvier."(NGK Agenda 2007:46).

- Alle lidmate is geroep om sendelinge te wees, waar hulle hul ook mag bevind (NGK Agenda 2007:46).

- Gelowiges leef in die alledaagse werklikheid. Alle gelowiges is voltydse verteenwoordigers van Christus op elke plek waar hulle hulself bevind. Kerkwees gebeur daarom binne elke lewensfeer. Sodoende word die skeiding tussen heilige ruimtes en sekulêre ruimtes opgehef (NGK Agenda 2007:47).

\section{'N NUWE MISSIONÊRE IDENTITEIT VIR DIE NG KERK - SAMEVATTING}

Die oorsig oor veral beleidsbesluite van die kerk dui aan dat daar in die tydperk wat deur Saayman as die era van die vierde golf (sedert 1990) aangedui is, belangrike kontoere van ' $n$ ontluikende missionêre ekklesiologie getrek is. Hierdie kontoere weerspieël baie van die missionêre renaissance wat in ekumeniese geledere en ook in ander denominasies sigbaar is. Dit sluit onder meer die volgende in:

- 'n Bewustelike missionêre identiteit wat in die NG Kerk se Gereformeerde identiteit veranker is;

- Die verstaan van die kerk as ' $n$ lewe in die Triniteit. Die verstaan van die Triniteit as 'n verhoudingstriniteit het tot gevolg dat die saak van gemeenskap en verhoudings in nadenke oor die kerk en sending beklemtoon word;

- Die herontdekking van die begrip Missio Dei. Die kerk se roeping is nie om te stuur nie, maar om opgeneem te word in en deelhebber te wees aan God se sending na die wêreld;

- Die sending van God mond uit in die sending van die kerk, sodat van gestuurde gemeentes gepraat word;

- Die kerk is 'n lewende interpretasie van die koninkryk en staan in diens van die ryk;

- Waardering vir die ekologie of plaaslike konteks van gemeentes en die alledaagse werklikheid waarbinne lidmate hulself bevind, soos veral duidelik geword het in die Seisoen van Luister;

- 'n Duidelike verbondenheid om by die genesing van die lande en diens aan plaaslike gemeenskappe betrokke te wees.

- 'n Verstaan van sending as die inkarnasie van die Evangelie, 'n konkrete boodskap vir konkrete mense in hulle alledaagse lewe - in die woorde van Saayman (2007:5) "being missionary while being human."

Hierdie kontoere van 'n ontluikende missionêre ekklesiologie dui aan dat die vierde golf omvangryker as Saayman se tipering van "tot die eindes van die aarde" is en dat sending in die NG Kerk 'n baie sterk plaaslike fokus gekry het. Hoewel dit nie binne die bestek van hierdie studie aan die orde gestel is nie, dui die meer as 170 gemeentes wat lid van die SAVGG is, sowel as verhale van diens aan plaaslike gemeenskappe (in Kruisgewys van Augustus 2010 word vyf gevallestudies aangeteken), daarop dat die ontluikende missionêre ekklesiologie gemeentelike 
praxis bepaal. Die NG Kerk bevind hom in 'n vierde golf wat die lewens van die meerderheid kerklidmate en predikante aanraak. Die omvangryke golf spoel sterk in die rigting van plaaslike gemeenskappe en die ontdekking dat nuwe grense oorskry kan word. Dit spiraal ook uit na gemeenskappe aan die "eindes van die aarde".

\section{BIBLIOGRAFIE}

The Archbishops' Council 2004. Mission Shaped Church, London:Church House.

Balia, D. \& Kim,K., 2010, Witnessing to Christ today (Edinburgh 2010 Vol.II), Oxford:Regnum.

Barrett, L.Y., Guder, D.L., Hobbs, W.C., Hunsberger, G.R., Stutzman, L.L., Van Kooten, J. et al. (eds.), 2004, Treasure in clay jars: Patterns in missional faithfulness, Grand Rapids:Eerdmans.

Brouwer, R., 2009, Geloven in gemeenschap. Het verhaal van een Protestantse Geloofsgemeenschap, Kampen:Kok.

Gesamentlike verklaring, 2006, Ons roeping tot Diens en Getuienis, Gesamentlike verklaring van die Nederduitse Gereformeerde Kerk, die Nederduitse Gereformeerde Kerk in Afrika, die Reformed Church in Africa en die Verenigende Gereformeerde Kerk in Suider-Afrika Aug. 2006.

Guder, D.L., 2000, The Continuing Conversion of the Church, Grand Rapids:Eerdmans.

Heyns, J.A., 1978, Dogmatiek, Pretoria: NG Kerkboekhandel.

Hirsch, A., 2006, The Forgotten Ways. Reactivating the Missional Church, Grand Rapids:Brazos.

Hofmeyr, J.W. en Kruger, P., Die NG Kerk en die era van verandering sedert 1990: Betekenis vir die NG Kerk se identiteit (Deel II) in NGTT Deel 50 nrs. 3\&4, 384-395

Keifert, P., 2007, Ons is nou hier .'n Nuwe era van gestuur-wees, Wellington:BM.

Kirk, J.A., 1999, What is Mission? Theological explorations, London: Darton, Longman \& Todd.

Kruisgewys 10/3, Augustus 2010.

McNeal, R., 2009, Missional Renaissance. Changing the scorecard for the Church, San Francisco: JosseyBass.

Newbegin, L., 1995 (Revised Edition), The Open Secret. An introduction to the theology of Mission. Grand Rapids: Eerdmans.

Niemandt, C.J.P., 2010, 5 Years of missional church - reflections on missional ecclesiology, referaat gelewer by die jaarlikse byeenkoms van die South African Missionary Society, Bloemfontein, 13-15 Januarie.

Nederduitse Gereformeerde Kerk 2010. Seisoen van Luister, besigtig op 20 Aug. 2010 by http://www. seisoenvanluister.co.za/produkte/kleingroepe/56-groei-oor-grense

Nederduitse Gereformeerde Kerk 2007. Die Kerkorde, Wellington:Bybelmedia.

Nederduitse Gereformeerde Kerk 2007. Algemene Sinode 2007. Besluiteregister, besigtig op 20 Aug. 2010 by http://www.ngkerk.org.za/documents/Besluiteregsiter\%202007\%20(F)\%20p193-p223.pdf

Nederduitse Gereformeerde Kerk 2007. Algemene Sinode 2007. Agenda Deel I.

Nederduitse Gereformeerde Kerk 2004. Algemene Sinode 2004. Agenda Deel II.

Nederduitse Gereformeerde Kerk 2002. Agenda Algemene Sinode 2002. Verslag A.8 Algemene Kommissie vir Gemeentebediening in Agenda.

Nederduitse Gereformeerde Kerk 2002. Algemene Sinode 2002. Bes/uiteregister, besigtig op 20 Aug. 2010 by http://www.ngkerk.org.za/besluitregister/2002\%20Besluiteregister.rtf

Nederduitse Gereformeerde Kerk. Algemene Sinode 1974. Ras, volk en nasie en volkereverhoudinge in die lig van die Skrif. Kaapstad: NG Kerk Uitgewers.

Protestantse Kerk in Nederland 2010. Kerk naar buiten besigtig op 26 Aug. 2010 by http://www.pkn.nl/ missionair/

Saayman, W., 2007, Being Missionary - Being Human. An overview of Dutch Reformed Mission, Pietermaritzburg: Cluster Publications.

Sinode van die Nederduitse Gereformeerde Kerk van Suid-Transvaal 2005, Handelinge.

Van Gelder, C., 2007, The ministry of the missional church: A community led by the Spirit, Grand Rapids: Baker.

Van Wyk, C., 2010, Van dominasie na diens, Kruisgewys 10/3, Augustus, 3.

Van Wyk, C., Marais, F., Simpson, N., 2009, Die vrou by die put (Deelnemersgids), Wellington: Bybel-Media. Venter, R., 2009, God after Darwin: The promise of Trinitarian Theology in NGTT Deel 50 nrs. 3\&4, 541-551. World Communion of Reformed Churches 2010. Message from the Uniting General Council 2010 Grand 
Rapids, United States. Ook besigtig op 20 Aug. 2010 by http://www.reformedchurches.org/docs/ $\underline{\text { UGCMessage.pdf }}$

\section{KEY WORDS}

Dutch Reformed Church

Missional ecclesiology

Mission history

Missional congregations

Missio Dei

\section{TREFWOORDE}

Nederduitse Gereformeerde Kerk

Missionêre ekklesiologie

Sendinggeskiedenis

Gestuurde gemeentes

Missio Dei

Prof. CJP (Nelus) Niemandt

Fakulteit Teologie

Universiteit van Pretoria

Pretoria

0001

Tel. +27 (0)124202383

+27 (0)824511670

e-pos: nelus@pixie.co.za

Facebook: Nelus Niemandt 